\title{
Head of US drug company takes Serbian post
}

Washington. If combativeness and an ability to stir controversy are what are needed to end a bloody civil war, then the Yugoslav government has found its man. Milan Panic, the founder, president and chief executive officer of ICN Pharmaceuticals Inc., in Costa Mesa, California, last week became prime minister of the remnants of Yugoslavia, which now includes the republics of Serbia and Montenegro.

Panic, a 62-year-old Serbian who immigrated to the United States in 1956, is no stranger to conflict. Over the past two decades, he has been embroiled in numerous confrontations with scientists, stockholders and the US government. ICN has been investigated by the Food and Drug Administration (FDA), a US House of Representatives oversight committee and twice by the Securities and Exchange Commission (SEC). More recently, Panic was widely condemned for promoting ribavirin, a drug developed by his company as an AIDS therapy; the FDA refused in 1987 to approve the drug for that use.

Those who know him say that it is Panic's personality rather than any real wrongdoing that has caused him problems. But even they agree that his aggressiveness and fiery temper may prove less than ideal for his new position, in which he will be working with the Yugoslav president, Slobodan Milosevic, to form a new government.

Panic, who by his own account arrived in the United States with a family and only $\$ 20$, has spent the past 32 years building ICN into a multi-million-dollar corporation. Along the way, his tactics have made him the target of several government probes, the first in the 1970 s, when ICN was accused of releasing inflated earnings potentials. The company settled with the SEC in 1977, not admitting to guilt but committing itself to new auditing policies.

The company gained even more notoriety in 1987 when it held a press conference to announce that ribavirin, which was developed by an ICN co-founder, had slowed the development of AIDS in men who had tested positive for the human immunodeficiency virus. The share price of the company's stock shot up, even though the FDA had approved the drug only for fighting respiratory infections in infants. Despite Panic's championing of ribavirin, the FDA did not approve the drug's use as an AIDS therapy, and some scientists view ICN's clinical trials with scepticism.

After all the publicity, the SEC began to investigate the company's promotional ac- tivities, and shareholders filed a class-action suit accusing ICN of improperly publicizing ribavirin to raise the price of its shares. Last year, ICN settled with the SEC, agreeing to abide by the law but neither denying nor admitting to wrongdoing. ICN also settled with the shareholders, paying $\$ 400,000$ in penalties and $\$ 200,000$ in expenses.

Some observers familiar with the company say that Panic was guilty more of indiscretion than of falsely promoting ribavirin. They describe him as being fervently enthusiastic about his company and unconcerned about upsetting FDA officials. $\mathrm{He}$ is said to run his own company with a firm hand. "Here's an obviously enormously creative guy whose inability to negotiate and work with people who want different things and have different styles is his shortcoming," says Jonathan Kwitney, the author of a forthcoming book on the ribavirin controversy.

Panic has long had a keen interest in politics, hosting lavish fund-raising events and donating generously to Democratic politicians. Now that he has plunged into politics, it remains to be seen whether the traits that made him a controversial figure in the United States will help him to make peace in the Balkan states.

Traci Watson

\section{New university funding council to reward potential}

London. The new body funding higher education in England plans to broaden the way it assesses the quality and quantity of university research by taking into account the potential of a department and the size of its active research staff. This is a departure from the system now used by the Universities Funding Council (UFC), which decides quality almost exclusively on a review of existing work and relies on student numbers to measure research volume.

The new methods are discussed in a document released this week* by the UFC and the Polytechnics and Colleges Funding Council (PCFC), the two bodies that will combine in April 1993 to form the Higher Education Funding Council for England (HEFCE). The UFC this year will distribute $£ 548$ million (US\$850 million) and the PCFC $£ 7.6$ million. The councils will reach a decision in the autumn.

The new method, which will be applied to the 1993-94 funding round, will follow the current UFC model of using a formula that includes measurements of research quality and volume of activity. As such, it will make considerable use of an exercise now under way to assess research, and is expected to concentrate the research funding further. For example, 25 institutions in England now receive 75 per cent of funds allocated for academic research.

The idea that departments with research potential should receive some sort of developmental funding reflects a concern on the part of the funding councils that a narrowly applied formula "would run the risk of ossification, and make it difficult for promising departments to develop their capacity". Although the amount of money involved is likely to be small, the move is being welcomed nonetheless.

Just how the research potential will be assessed is more problematic. A system that would judge a research plan submitted by a department would require the new council to have expertise it does not possess. The funding councils would like to use the existing approach that relies on a formula. A possible compromise might be to consider those departments that flunk the current assessment exercise but present a respectable research strategy.

The councils want to exclude departments with a high volume of research and whose parent institutions are otherwise well funded and in a position to help them. Departments that could be expected to get funds from elsewhere are also likely to be excluded.

Under the UFC method, research volume is measured by counting the number of students in a department. Although the councils recognize that these students contribute to the research activity, they consider that, like other students, they are essentially working towards a degree. However, the contribution of research students will be taken into account in the assessment under way. The new approach will also be limited to active researchers.

The new council will retain the UFC's practice of measuring the amount of contract work done by a department. Although departments are expected to recover all the costs of contract research, there are some situations, such as research sponsored by the British government or the European Communities, where the work is fundamental and may need additional support.

lan Mundell

* The Funding of Research, by the Higher Education Funding Council for England (available from the External Relations Unit, the Higher Education Funding Council for England, Northavon House, Coldharbour Lane, Bristol BS16 10D). 